\title{
FAKTOR-FAKTOR YANG MEMPENGARUHI KELENGKAPAN DOKUMENTASI ASUHAN KEPERAWATAN DI RUANG BEDAH RSUD dr. SOEKARDJO KOTA TASIKMALAYA
}

\author{
Elgiana Ayu Noviari ${ }^{1}$, Dwi Dahlia Susanti ${ }^{2}$
}

\begin{abstract}
ABSTRAK
Berdasarkan penelitian Nuryani (2014) pada triwulan I tahun 2013 diketahui bahwa ketidaklengkapan dokumentasi asuhan keperawatan mencapai 70,5\%. Hal ini akan berdampak pada keakuratan isi rekam medis serta aspek legal rekam medis. Penelitian kualitatif fenomenologi ini dilakukan untuk mengetahui faktor-faktor yang mempengaruhi kelengkapan dokumentasi asuhan keperawatan di ruang bedah RSUD dr.Soekardjo Tasikmalaya. Informan dipilih berdasarkan kriteria tertentu dengan menggunakan metode purposif. Enam informan yang berpartisipasi dalam penelitian ini adalah perawat ruang rawat inap bedah RSUD dr. Soekardjo Tasikmalaya. Data diperoleh melalui wawancara yang mendalam. Wawancara direkam dengan menggunakan handphone dan selanjutnya dibuat transkrip wawancara. Analisis data dilakukan dengan teknik Miels and Huberman sehingga diperoleh tiga tema. Hasil penelitian ini menunjukan bahwa dokumentasi asuhan keperawatan dilakukan dari mulai pasien itu datang lalu dilakukan pemeriksaan dan selanjutnya dilakukan dokumentasi asuhan keperawatan. Kendala yang dihadapi dalam proses dokumentasi asuhan keperawatan diantaranya adalah kurangnya SDM, tingginya beban kerja, pengetahuan perawat tentang dokumentasi yang dikatakan lengkap serta motivasi dalam proses dokumentasi asuhan keperawatan. Adanya audit, peninjauan kembali terhadap dokumen rekam medis dan pemberian motivasi kerja pada perawat menjadi sebuah solusi untuk meminimalisir ketidaklengkapan dokumentasi asuhan keperawatan. Hasil penelitian ini memberikan implikasi terhadap rekam medis untuk meminimalisir ketidaklengkapan pengisian dokumentasi asuhan keperawatan agar mutu pelayanan kesehatan dapat meningkat.
\end{abstract}

Kata Kunci: Kelengkapan Dokumentasi asuhan keperawatan.

\section{ABTRACT}

The research performed by Nuryani (2014) in trimester I of 2013 showed the incompleteness of nursing proses documentation of $70.5 \%$. This result would influence the accuracy as well as the legality of medical record. This phenomenology qualitative research wont's to know the factors influencing the completeness of nursing proses documentation at the Surgery Room of RSUD dr Soekardjo Tasikmalaya. The informant were selected with purposive method. The informant of this research were six nurses of the Hospitalizing Room of Surgical Section. The data was collected by in-depth-interview. The interview was recorded by using cellular phone and then was made the transcript. The data was analyzed using Miels and Huberman technique and got three themes. The result of this research showed that the record of the nursing proses documentation begin the patient come to the room after that the nurses do examination and than nurses make a dokumentasion; contrain from nursing proses dokumentation is the lack of human resources, the high working burden on the nurses, knowledge and motivation to do their job. This problem could be solved by auditing and reviewing the nursing proses documentation, and giving motivation to the nurses. Hopefully the solutions could minimize the incompleteness of the nursing examination records. The result of this research gave implication on the medical record to minimize the incompleteness of the nursing proses documentation and therefor can improve the quality of health service.

Key Word : The completeness of nursing documentation 


\section{PENDAHULUAN}

Berdasarkan Peraturan Menteri Kesehatan Republik Indonesia Nomor 269/Menkes/Per/III/2008 Pasal 1, yang dimaksud dengan rekam medis adalah berkas yang berisi catatan dan dokumen tentang identitas pasien, pemeriksaan, pengobatan, tindakan dan pelayanan lain yang telah diberikan kepada pasien. Dalam UU No.44 tahun 2009 ayat 1 (satu) tentang rumah sakit menyatakan bahwa penyelenggaraan rekam medis yang baik pada setiap pelayanan kesehatan dapat meningkatkan mutu pelayanan kesehatan. Rekam medis dapat dikatakan lengkap apabila terisinya data identifikasi pasien, pelaporan penting, autentifikasi serta menggunakan tata cara pendokumentasian yang baik. Pengisian yang tidak lengkap terhadap rekam medis akan berdampak pada fungsi dari rekam medis yaitu administratif, legal, financial, research, education, documentation (Hatta, 2013).

Rumah sakit sebagai salah satu sarana pelayanan kesehatan yang melakukan pelayanan rawat jalan maupun rawat inap wajib untuk membuat rekam medis. Penanggung jawab pengisian rekam medis adalah Dokter umum, dokter spesialis, dokter gigi dan dokter spesialis yang melayani pasien di rumah sakit, dokter tamu, residen, perawat, perawat gigi, bidan, tenaga laboratorium klinik, gizi, anestesi, penata rontgen, rehabilitasi medik (Depkes $\mathrm{RI}, 2006)$.

Peran perawat sebagai salah satu tenaga kesehatan mempunyai kontribusi besar bagi pelayanan kesehatan dalam upaya peningkatan mutu pelayanan kesehatan. Dalam upaya peningkatan mutu, seorang perawat harus mampu melaksanakan asuhan keperawatan sesuai standar, dari mulai pengkajian sampai dengan evaluasi berikut dokumentasinya (Deswani, 2011). Dokumentasi asuhan keperawatan mempunyai makna yang penting dilihat dari berbagai aspek seperti aspek hukum dimana semua catatan informasi tentang klien merupakan dokumentasi resmi dan bernilai hukum yang dapat dipergunakan sebagai barang bukti di pengadilan, aspek kualitas pelayanan akan meningkatkan mutu pelayanan perawat, aspek komunikasi dilihat dari dokumentasi keperawatan yang dijadikan sebagai pedoman dalam memberikan asuhan keperawatan maka dari itu dokumentasi keperawatan harus diisi dengan lengkap, aspek keuangan dokumentasi keperawatan dapat dipergunakan sebagai acuan atau pertimbangan dalam biaya keperawatan bagi klien.

Pendokumentasian dan pelaporan dikatakan berkualitas apabila data yang ditulis sesuai dengan fakta, data akurat, lengkap, data langsung dicatat saat itu, bersifat rahasia dan terorganisir (Haryanto, 2008). Apabila dokumentasi asuhan keperawatan tidak diisi dengan lengkap maka hal ini akan berdampak terhadap makna penting dari dokumentasi asuhan keperawatan yang dilihat dari berbagai aspek yaitu aspek hukum, kualitas pelayanan, komunikasi, keuangan, pendidikan, penelitian dan akreditasi.

Berdasarkan penelitian Nuryani (2014) pada triwulan I tahun 2013 menunjukan bahwa ada hubungan antara pengetahuan perawat dengan ketidaklengkapan pengisian dokumentasi asuhan keperawatan di ruang bedah RSUD dr. Soekardjo Tasikmalaya dengan presentase ketidaklengkapan mencapai $70,5 \%$, dari hasil tersebut dapat disimpulkan bahwa ketidaklengkapan pengisian dokumentasi asuhan keperawatan lebih banyak dibanding dengan kelengkapannya. Selain itu ada juga penelitian dari Maulana (2014) yang dilakukan di RSUD Ciamis menunjukan bahwa ada hubungan antara motivasi perawat dengan ketidaklengkapan pengisian dokumentasi asuhan keperawatan Dari kedua penelitian tersebut dapat disimpulkan bahwa faktor yang menyebabkan ketidaklengkapan dokumentasi asuhan keperawatan diantaranya adalah pengetahuan dan motivasi. Berdasarkan komunikasi personal, perawat ruang bedah (2015) sebagai studi 
pendahuluan yang dilakukan dengan melakukan wawancara kepada salah seorang perawat di ruang bedah RSUD dr. Soekardjo Tasikmalaya didapatkan informasi mengenai kendala yang sering sekali di hadapi perawat dalam pengisian dokumentasi asuhan keperawatan diantaranya, kesadaran dari perawat dalam pengisian dokumentasi asuhan keperawatan dengan lengkap sebagai legal aspek yang masih kurang, pengetahuan perawat yang masih kurang mengenai penentuan

\section{METODE PENELITIAN}

$\begin{array}{lcc}\text { Metode } & \text { pada penelitian ini } \\ \text { menggunakan } & \text { penelitian kualitatif } \\ \text { fenomenologi } & \text { untuk mengidentifikasi } \\ \text { pengalaman informan tentang suatu }\end{array}$ fenomena yaitu faktor-faktor yang mempengaruhi kelengkapan pengisian dokumentasi asuhan keperawatan. Prosedur dalam pemilihan sampel peneliti menggunakan teknik purposive sampling dengan kriteria Inklusi perawat yang memiliki masa kerja cukup lama yaitu $\geq 5$ tahun sehingga memiliki banyak

\section{HASIL PENELITIAN}

Bagian ini akan diuraikan keseluruhan tema yang telah didapatkan berdasarkan informasi yang diperoleh dari informan. Berdasarkan lima tujuan khusus penelitian didapatkan enam tema yang menggambarkan faktor-faktor yang mempengaruhi kelengkapan dokumentasi asuhan keperawatan. Tema-tema tersebut akan diuraikan sesuai dengan penomoran 1-3. Tujuan khusus pertama proses pendokumentasian asuhan keperawatan dijelaskan dalam tema 1 tentang proses dokumentasi asuhan keperawatan. Tujuan khusus kedua kendala-kendala yang dihadapi dalam pengisian dokumentasi asuhan keperawata dijelaskan dalam tema 2 tentang kendala-kendala yang dihadapi dalam pengisian dokumentasi asuhan keperawatan. Tujuan khusus ketiga tentang cara mengatasi kendala-kendala yang dihadapi dalam pengisian dokumentasi diagnosis ataupun dalam pencatatan dokumentasi asuhan keperawatan, tanggungjawab serta malas atau tidaknya perawat tersebut dalam mengisi dokumentasi asuhan keperawatan secara lengkap dan fluktuasi jumlah pasien yang selalu meningkat. Berdasarkan latar belakang tersebut maka dilaksanakan penelitian tentang faktor-faktor yang mempengaruhi ketidaklengkapan pengisian dokumentasi asuhan keperawatan.

pengalaman, masih aktif dan terlibat langsung dalam proses pemberian pelayanan kesehatan dan sukarela serta terbuka memberikan informasi dalam wawancara. Informan pada penelitian ini sebanyak 6 (enam) orang. Instrumen merupakan human instrument yang dibantu dengan recorder dan alat tulis. Analisis dengan menggunakan model Miels yang terdiri dari reduksi data, penyajian data dan menarik kesimpulan.

asuhan keperawatan dijelaskan dalam tema 3 tentang solusi untuk mengatasi kendala dalam dokumentasi asuhan keperawatan.

Tujuan khusus: proses pendokumentasian asuhan keperawatan.

Tema 1: Proses dokumentasi asuhan keperawatan.

Pencatatan atau pendokumentasian merupakan tindakan legal, karena dokumentasi merupakan media komunikasi. Proses dokumentasi asuhan keperawatan tidak hanya menulis data pada format yang tersedia, tetapi juga menitikberatkan pada proses dan hasil pencatatan. Berikut ungkapan informan mengenai proses dokumentasi asuhan keperawatan:

"Awal paien datang, smrs, anamneses, riwayatnya ditanya, isi askepnya, isi etiologinya kemudian capernya dilanjutkan" (informan 1). 


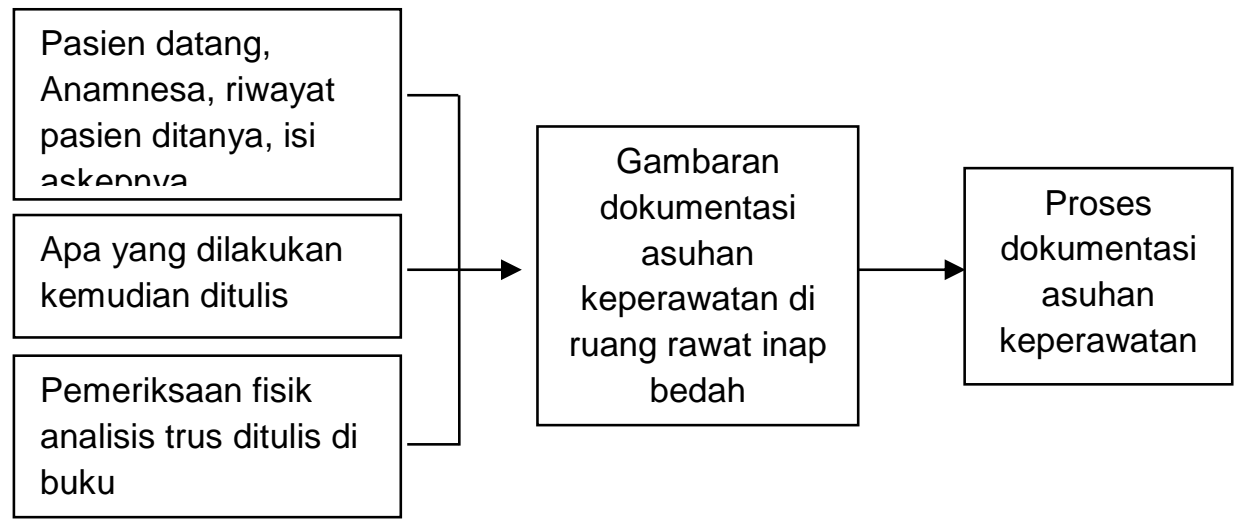

Bagan 1. Analisis tema proses dokumentasi asuhan keperawatan

"Berawalnya dari pasien masuk kiriman dari UGD atau dari poliklinik, kita anamnesa keluhannya apa setelah kita kaji ke pasien baru kita dokumentasikan hasil pengkajian sama tindakannya. Jadi apa yang dilakukan kemudian dirulis gitu. Pengkajian, perencanaan, pelaksanaan, kemudian evaluasi" (Informan 2).

Tujuan Khusus: kendala-kendala yang dihadapi dalam pengisiandokumentasi asuhan keperawatan

Tema 2: Kendala-kendala yang dihadapi dalam pengisian dokumentasi asuhan keperawatan.

Sumber daya manusia merupakan komponen yang paling penting dalam proses dokumentasi asuhan keperawatan. Karena kualitas dari isi dokumentasi asuhan keperawatan tersebut akan tergantung dengan kualitas dari sumber daya manusianya. Ketika beban kerja meningkat dan sumber daya manusia tidak memadai maka akan berpengaruh terhadap hasil kerja yang kurang maksimal. Berikut ungkapan dari informan mengenai sumber daya manusia yang masih kurang di saat beban kerja yang tinggi:

"Karna pekerjaannya, pekerjaannya terlalu banyak lupa kan kesana kemari jadikan, pekerjanya juga terbatas misalnya disini tiga orang merawat delapan orang itu kan kegiatannya ke ok kesini konsul kemanamana tidak cukup hanya tiga orang" (Informan 1). "ya kurang SDM heeh riweh pasien 33 yang dines berapa orang" (Informan 4).

"kendala yang dihadapi biasanya dari jumlah pasien kita 33 pasien tenaga cuma 15 orang pagi siang sore dari beban kerja, belum lagi kita diruangan disinikan banyak tindakan beres itu jam 12-jam 1" (Informan 2).

"Jadi akar permasalahannya ke proporsi perbandingan antara jumlah pasien dengan tenaga perawat disini kalau idealnya 25-28 orang disini kita Cuma 13 orang disini" (Informan 2).

Kurangnya sumber daya manusia akan berdampak terhadap peningkatan beban kerja. Beban kerja yang semakin hari semakin bertambah akan memepengaruhi motivasi seseorang dalam berkerja dan hal ini akan berpengaruh juga terhadap hasil pekerjaanya.

Hal ini pun sama dengan apa yang dihadapi oleh perawat di ruang rawat inap bedah yang mempunyai beban kerja yang cukup tinggi karena dalam satu hari mereka menangani 33 pasien dengan jumlah sumber daya manusia yang hanya 15 orang dibagi ke dalam tiga shift. Hal ini pun di paparkan oleh informan:

"karna pekerjaanya, pekerjaan terlalu banyak lupa kan banyak kesana kemari jadikan pekerjaanya juga terbatas misalnya disini 3 orang merawat delapan orang itu kan kegiatannya ke OK ke sini konsul kemana-mana tidak cukup hanya 3 orang satu kepala tim pasiennya dua jadi kalau mau selesai apa yang belum terselesaikan 
selesaikan dahulu baru dilanjutkan ke yang berikutnya" (Informan 1).

"Ketidaklengkapan si karena beban kerja mungkin ketika kita nulis ada cairan infus habis atau apa gitu ada tindakan-tindakan yang lain sementara kita kan tidak bisa manantikan keluhan pasien daripada menulis tapi pasien gawat kan kita harus tindakan dulu ke pasien" (Informan 2). "paling karena kesibukan ajah si kan banyak yah pasiennya cepet paling karena itu ajah" (Informan 3).

"kalau kendala satu karena kesibukan banyaknya pasien sama banyaknya perawat yang jaga terutama malam pasien 33 yang jaga Cuma 2, sore pasien 33 Cuma 3, jadi karena kesibukan jadi ada yang kelewat tapi tidak kelewat sampai sampai tidak diisi" (Informan 6).

$$
\text { Kata Kunci }
$$

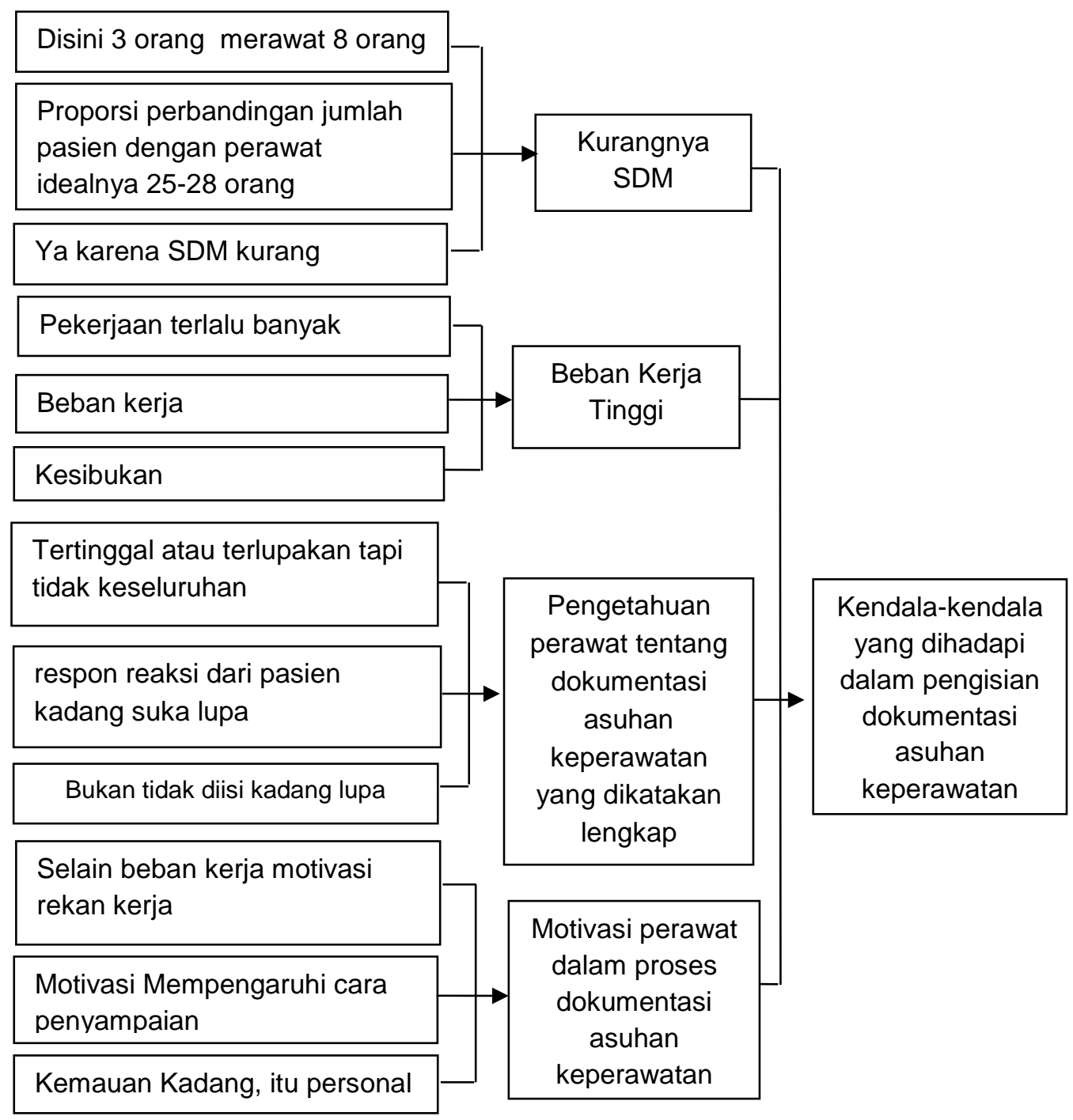

Bagan 2. Analisis tema Kendala-kendala yang dihadapi dalam pengisian dokumentasi Asuhan Keperawatan.

Dokumentasi asuhan keperawatan dikatakan lengkap apabila semua item dalam formulir diisi dengan lengkap. Apabila satu item saja tidak diisi dalam sebuah formulir, maka formulir itu dikatakan tidak lengkap. Menurut informan asuhan keperawatan sudah diisi dengan lengkap namun masih ada sebagian item yang masih 
sering lupa untuk diisi. Berikut ungkapan dari informan:

" lupa ngisi apanya? Palingg karna kan disini perawat tidak hanya nulis ajah pekerjaan dulu baru nanti nulis. Yaa kalo secara rinci mungkin ada yang tertinggal juga namanya manusia ada lupanya ada gimananya kalo sibuk mungkin pasti ada yang lupa karna programnya banya pasti mungkin ada yang lupa ajah diantara sekian ada yang tertinggal atau terlupakan tapi tidak keseluruhan satu status kosong tidak, paling Cuma satu poin satu poin" (informan 1).

"Kalau biasanya si da ehh lupa itu karna jumlah pasien yang banyak tindakan banyak belum nulis kemudian respon reaksi dari pasien yang kita beri asuhan kadang suka lupa" (informa 2).

"Asuhan keperawatannya, evaluasi kadang dalam askep evaluasi suka terlupakan, tanda tangan dalam implementasi sama waktu pengerjaan kadang lupa, rata-rata evaluasi lupa lah bukan tidak diisi kadang lupa" (informa 6).

Motivasi dalam bekerja merupakan salah satu faktor yang mempengaruhi seseorang bekerja dengan maksimal. Partisipan mengungkapkan hal yang sama mengenai motivasi kerja yang dapat mempengaruhi hasil pekerjaan yang maksimal. Berikut ungkapan dari informan:

"ketidaklengkapan siii karna beban kerja, selain beban kerja paling motivasi kerja rekan, soalnya ada sebagian mau, sebagian karakteristiknya beda-beda ada yang malas" (Informan 2).

"Motivasi mempengaruhi terutama cara penyampaian ke pasien pemberitahuan istilahna teh kieu penyuluhan ke pasiennya" (Informan 5).

"kalau kemauan kadang itu persoalan yah kadang ada tapi rata-rata karena kesibukan" (informan 6).

Tujuan Khusus: cara mengatasi kendala-kendala yang dihadapi dalam pengisian dokumentasi asuhan keperawatan Tema 3: Solusi untuk mengatasi kendala dalam dokumentasi asuhan keperawatan.
Audit kelengkapan dokumentasi asuhan keperawat di adakan guna meminimalisir adanya ketidaklengkapan dokumen rekam medis khususnya ashuan keperawatan yang akan berpengaruh terhadap keakuratan data yang ada pada dokumen rekam medis. Berikut ungkapan informan mengenai audit kelengkapan dokumen rekam medis:

"Audit biasanya dilakukan per ruangan kepala ruangan" (Informan 1).

"Audit biasanya dilakukan 3 bulan sekali dari pihak keperawatan suka ada per ruangan" (Informan 2).

"Audit ada kadang kalo kosong kan dikembaliin lagi ke kita heeh, kalo pengisiannya kurang lengkap dikembalikan kesini harus diis" "(Informan 3).

Dokumentasi asuhan keperawatan dikatakan lengkap apabila semua komponen yang ada pada formulir bisa terisi tanpa ada yang tertinggal. Apabila pada formulir asuhan keperawatan ada satu poin saja tidak diisi maka formulir tersebut dinyatakan tidak lengkap. Oleh karena itu untuk mencegah hal itu terjadi harus ada tinjauan kembali terhadap dokumentasi asuhan keperawatan sehingga isinya lengkap dan akurat. Berikut ungkapan informan mengenai tinjauan kembali dokumentasi asuhan keperawatan.

"kan dilihat misalnya hari ini masuk besok kan dilihat lagi atau nanti sama yang sore dilihat lagi diisi gitu" (Informan 1).

"untuk mengecek dokumentasi asuhan keperawatan atau pasien pulang kita kontrol di dokumen kalau misalnya ada yang belum diisi harus diisi diingatkan lagi" (Informan 2). "sering diingatkan, misalnya ada yang kososng atau dines malem ada yang belum terisi yang dines malem ketika cek dan ricek perawatnya masih ada suruh nulis dulu trus sering dijelaskan" (Informan 6).

Pemberian motivasi kepada para perawat akan membantu meningkatkan semangat para perawat dalam bekerja. Hal ini pun akan berpengaruh terhadap hasil dari kerja para perawat. Berikut pemeparan dari informan mengenai kepala ruangan dan 
supervisi memberikan motivasi kepada para perawat:

"motivasi kepala, wakil, manajemen disini memebrikan motivasi itu dari luar" (Informan 6) "mengatasinya dari manajemen kita memberikan motivasi secara manajerial memberikan motivasi mengingatkan rekanrekan pelaksana untuk menulis apa yang kita kerjakan" (Informan 2).

Kata kunci

Kategori

Tema

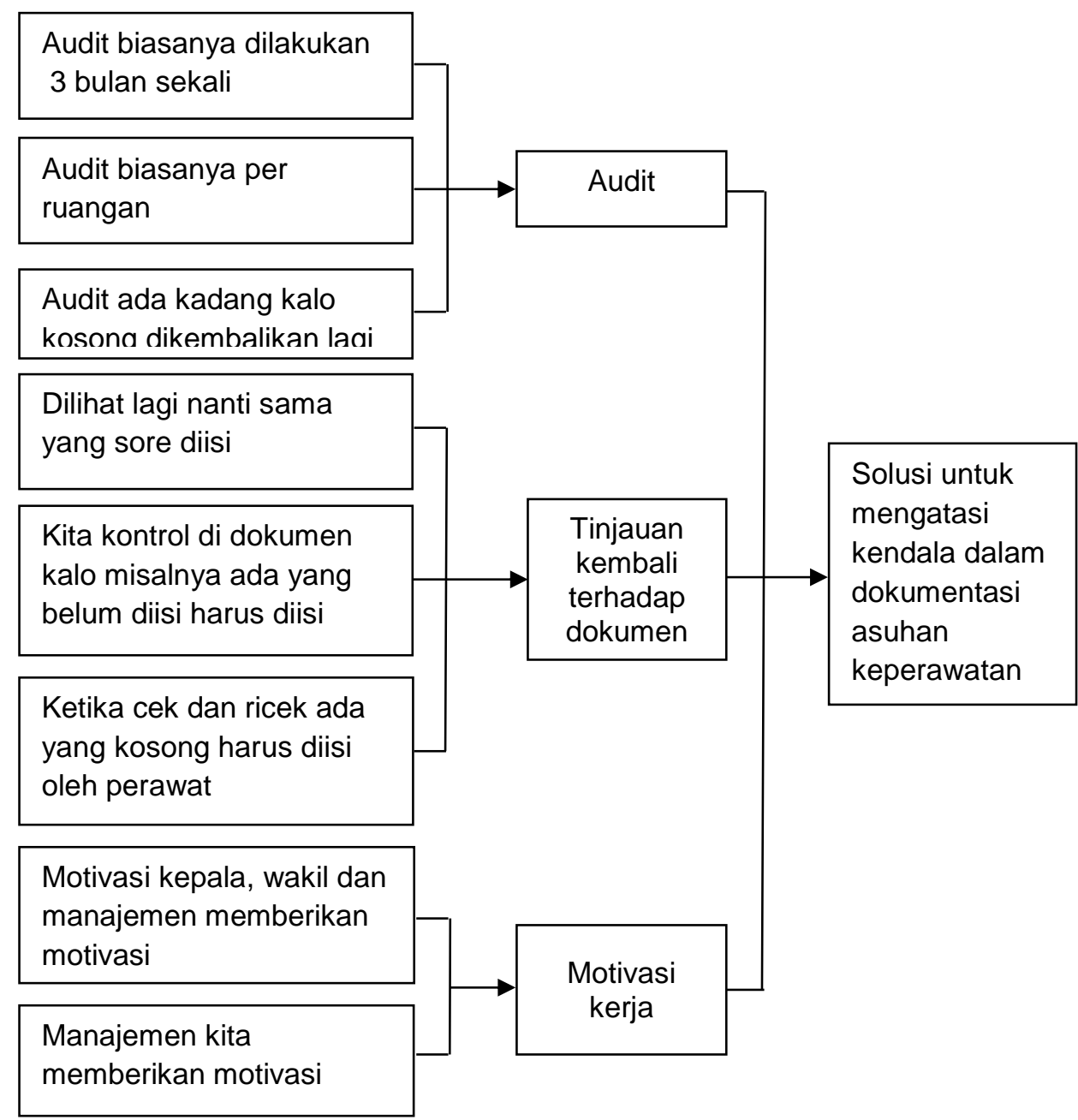

Bagan 3. Solusi untuk mengatasi kendala dalam dokumentasi asuhan keperawata

\section{PEMBAHASAN}

1. Proses Pendokumentasian Asuhan Keperawatan

Perawat sebagai salah satu tenaga yang mempunyai kontribusi besar bagi pelayanan kesehatan berperan penting dalam upaya peningkatan mutu pelayanan kesehatan . dalam upaya peningkatan mutu,seorang perawata harus mampu melaksanaka asuhan keperawatan sesuai standar, yaitu mulai dari pengkajian sampai dengan evaluasi berikut dokumentasinya (Deswani, 2011). Hasil penelitian menunjukan bahwa proses dokumentasi asuhan keperawatan berawal dari pasien masuk kiriman dari UGD atau dari poliklinik, kita anamnesa keluhannya apa setelah kita kaji ke pasien baru kita dokumentasikan hasil pengkajian sama tindakannya. Pengkajian, perencanaan, pelaksanaan, kemudian evaluasi. Pencatatan atau 
pendokumentasian merupakan tindakan legal, karena dokumentasi merupakan media komunikasi. Dokumentasi bukan hanya sekedar menuliskan sesuatu dalam lembar pencatatan, tetapi harus lebih dahulu memikirkan dan menganalisis apa yang akan dan harus dicatat (Hatta, 2013).

2. Kendala-Kendala yang Dihadapi dalam Pengisian Dokumentasi Asuhan Keperawatan

Hasil penelitian menunjukan bahwa kendala-kendala yang dihadapi dalam pengisian dokumentasi ashuan keperawatan diantaranya adalah:

a. Kurangnya sumber daya manusia

Perawat di ruang bedah RSUD dr. Soekardjo kota Tasikmalaya hanya berjumlah 15 orang dengan jumlah pasien yang dirawat dalam satu hari yaitu 33 orang. Kurangnya sumber daya manusia ini berdampak terhadap tingginya beban kerja para perawat dan berdampak pula pada ketidaklengkapan dokumentasi asuhan keperawatan. Sumber daya manusia kesehatan adalah seseorang yang bekerja secara aktif di bidang kesehatan, baik yang memiliki pendidikan formal kesehatan maupun tidak yang untuk jenis tertentu memerlukan kewenangan dalam melakukan upaya kesehatan. Kurangnya sumber daya manusia akan berdampak terhadap peningkatan beban kerja. Oleh karena itu harus adanya perencanaan sumber daya manusia agar dapat menurunkan beban kerja sehingga hasil dari pekerjaan pun menjadi lebih maksimal. Menurut Kepmenkes No 81/MENKES/SK/I/2004 tentang Pedomanan Penyusunan Perencanaan SDM Kesehatan di tingkat Propinsi, Kab/Kota serta Ruma Sakit.

b. Tingginya beban kerja

Kurangnya sumber daya manusia di ruang bedah RSUD dr. Soekardjo kota Tasikmalaya berdampak terhadap peningkatan beban kerja para perawat. Jumlah perawat hanya 15 orang dengan pasien 33 dalam satu hari. Dari hasil observasi dapat dilihat bahwa perawat melakukan observasi terhadap pasien dimulai dari jam delapan pagi selain observasi perawat pun mempunyai tugas untuk melakukan dokumentasi asuhan keperawatan dan bisa selesai maksimal sampai jam 12 siang.

Menurut Moekijat dalam Mastini (2013) beban kerja adalah volume dari hasil kerja yang dihasilkan oleh sejumlah pegawai dalam suatu bagian tertentu. Jumlah pekerjaan yang harus diselesaikan oleh sekelompok atau seseorang dalam waktu tertentu atau beban kerja dapat dilihat pada sudut pandang objektif dan subjektif. Beban kerja perawat adalah seluruh kegiatan atau aktivitas yang dilakukan oleh seorang perawat selama bertugas di suatu unit pelayanan keperawatan. Menurut Gillies dalam Utami (2006) beban kerja perawat bersumber pada pekerjaan keperawatan dan administrasi. Sebagian besar pekerjaan perawat masih berkaitan dengan administrasi.

c. Pengetahuan perawat tentang dokumentasi asuhan keperawatan yang dikatakan lengkap

Dokumentasi bukan hanya sekedar menuliskan sesuatu dalam lembar pencatatan, tetapi harus lebih dahulu memikirkan dan menganalisis apa yang akan dan harus dicatat (Hatta, 2013). Hasil penelitian menunjukan bahwa dokumentasi asuhan keperawatan di ruang bedah RSUD dr. Soekardjo kota Tasikmalaya telah lengkap. Namun terkadang dalam proses dokumentasi asuhan keperawatan masih ada yang terlewat tidak diisi hal ini disebabkan oleh tingginya kesibukan perawat di ruang rawat inap bedah. Dari pernyataan perawat tersebut dapat disimpulkan bahwa pengetahuan perawat tentang kelengkapan dokumentasi asuhan keperawatan dianggap belum sepenuhnya mengetahui. Pengetahuan terhadap kelengkapan dokumentasi asuhan keperawatan tersebut dapat berpengaruh terhadap pelaksanaan pekerjaannya. Dimana ketika seorang perawat lupa tidak mengisi dokumentasi asuhan keperawatan walaupun hanya satu poin saja akan 
dianggap biasa saja tanpa adanya kemauan untuk merubah kebiasaan tersebut.

Menutut Hatta (2013) Rekam medis dapat dikatakan lengkap apabila terisinya data identifikasi pasien, pelaporan penting, autentifikasi serta menggunakan tata cara pendokumentasian yang baik. Apabila rekam medis tidak di isi dengan lengkap maka hal ini akan berdampak pada keakuratan isi rekam medis serta aspek kelegalan rekam medis tersebut menjadi tidak sah. Selain itu juga pengisian yang tidak lengkap terhadap rekam medis pun akan berdampak pada fungsi dari rekam medis yaitu administratif, legal, financial, research, education, documentation.

d. Motivasi perawat dalam proses

dokumentasi asuhan keperawatan

Motivasi seseorang dalam mengisi dokumentasi asuhan keperawatan akan sangat berpengaruh terhadap kualitas data yang ada pada dokumen rekam medis tersebut. Berdasarkan hasil penelitian menunjukan bahwa motivasi menjadi salah satu faktor yang mempengaruhi pekerjaan. Ketika beban kerja di ruang bedah tinggi maka motivasi kerja dari perawat pun semakin menurun namun tidak semua perawat memiliki motivasi yang rendah, tergantung terhadap perawat itu sendiri. Menurunya motivasi seorang perawat akan berpengaruh terhadap pemberian pelayanan kesehatan pada pasien terutama cara penyampaian informasi kesehatan pada pasien.

Motivasi adalah karakteristik psikologis manusia yang memberi kontribusi pada tingkat komitmen seseorang. Hal ini termasuk faktor-faktor yang menyebabkan, menyalurkan dan mempertahankan tingkah laku manusia dalam arah tekad tertentu. (Nursalam, 2008).

3. Cara Mengatasi Kendala-Kendala yang Dihadapi dalam Pengisian Dokumentasi Asuhan Keperawatan

Hasil penelitian menunjukan bahwa cara mengatasi kendala-kendala yang dihadapi dalam pengisian dokumentasi ashuan keperawatan diantaranya adalah: a. Audit kelengkapan dokumentasi asuhan keperawatan

Audit dilakukan sebagai upaya meminimalisir ketidaklengkapan dokumentasi asuhan keperawatan. Audit ini dilakukan setiap 3 bulan sekali yang dihadiri seluruh kepala ruangan rawat inap. Audit kelengkapan dokumen rekam medis dilakukan dengan adanya analisi kuantitatif dan kualitatif terhadap isi dari dokumen rekam medis tersebut.

Menurut Huffman (1997) Analisis kuantitatif dilakukan oleh praktisi informasi kesehatan untuk mengidentifikasi area catatan medis yang tidak lengkap, seperti tidak ditemukannya laporan patologi jaringan yang telah dikeluarkan pada waktu operasi. Pada proses analisis kuantitatif terdapat empat komponen review catatan medis yaitu mongkoreksi identifikasi pasien pada setiap formulir, kehadiran semua laporan yang perlu, autentifikasi yang diharuskan pada entri dan praktek pencatatan yang baik. Analisis kualitatif medis adalah kegiatan analisis dokumen rekam medis yang bertujuan untuk mengetahui sejauh mana kualitas pelayanan medis yang diberikan kepada pasien berdasarkan pemanfaatan kelengkapan informasi medis.

b. Tinjauan kembali terhadap dokumentasi asuhan keperawatan

Dokumentasi asuhan keperawatan dikatakan lengkap apabila semua komponen yang ada pada formulir bisa terisi tanpa ada yang tertinggal. Oleh karena itu untuk menghindari adanya pengisian yang tertinggal perawat melakukan tinjauan kembali terhadap isi dokumentasi asuhan keperawatan. Apabila dalam dokumentasi asuhan keperawatan ada yang tertinggal maka harus dilengkapi oleh perawat yang bertanggung jawab.

Komponen dasar analisi kuantitatif mencakup review catatan medis (Hatta, 2013) diantaranya yaitu mengoreksi informasi identifikasi pasien terdiri dari nama lengkap pasien, nomor rekam medis pasien, alamat lengkap, usia pasien saat ini yang diperoleh secara lisan dari pasien atau 
berdasarkan data identitas, orang yang dapat dihubungi yaitu keluarga atau rekan terdekat

c. Kepala ruangan dan manajemen memberikan motivasi kepada para perawat

Motivasi sangat dibutuhkan oleh para perawat dengan beban kerja yang cukup tinggi adanya motivasi dari pimpinan dan manajemen akan membantu para perawat untuk lebih termotivasi lagi dalam melakukan pelayanan kesehatan dan proses dokumentasi asuhan keperawatan

\section{KESIMPULAN}

Berdasarkan hasil penelitian menunjukan bahwa Proses dokumentasi asuhan keperawatan berawal dari pasien masuk kiriman dari UGD atau dari poliklinik, melakukan pengkajian, perencanaan, pelaksanaan, kemudian evaluasi. Kendalakendala yang dihadapi dalam pengisian dokumentasi asuhan keperawatan diantarnya yaitu kurangnya sumber daya manusia dan tingginya beban kerja pengetahuan perawat tentang kelengkapan dokumentasi asuhan keperawatan dianggap belum sepenuhnya mengetahui dan motivasi perawat akan berpengaruh terhadap pemberian pelayanan kesehatan pada pasien terutama cara penyampaian informasi kesehatan pada pasien. Cara yang dilakukan perawat mengatasi kendalakendala dalam dokumentasi asuhan

\section{REFERENSI}

Depkes, RI. (2006). Pedoman Penyelenggaraan dan Prosedur Rekam Medis Rumah Sakit di Indonesia Revisi II. Jakarta: Direktorat Jenderal Bina Pelayanan Medik.

Deswani. (2011). Proses Keperawatan dan Berpikir Kritis. Jakarta : Salemba Medika..

Haryanto. (2008). Konsep Dasar Keperawatan dengan Pemetaan Konsep (Concept Mapping). Jakarta. Salemba Medika.

Hatta, G. (2013). Pedoman Manajemen Informasi Kesehatan di sarana pun dapat dilakukan dengan maksimal. Menurut Nursalam (2011), kebutuhan, motivasi dimiliki seseorang pada saat belum mencapai tingkat kepuasan tertentu dalam kehidupannya. Kebutuhan yang telah terpuaskan tidak akan lagi menjadi motivator. Teori keadilan didasarkan pada asumsi bahwa faktor utama dalam motivasi pekerjaan adalah evaluasi individu atau keadilan dari penghargaan yang diterima. Individu akan termotivasi jika hal yang mereka dapatkan seimbang dengan usaha yang mereka kerjakan.

perawat diantaranya adalah audit kelengkapan dokumentasi asuhan keperawatan, tinjauan kembali terhadap dokumentasi asuhan keperawatan dan Kepala ruangan dan manajemen memberikan motivasi kepada para perawat.

Implikasi dari penelitian ini adalah sebagai evaluasi terhadap kelengkapan dokumentasi yang dilakukan oleh seluruh tim kesehatan yang adadi Rumah Sakit sebagai salah satu aspek legal yang sangat penting dan indikator dari kualitas suatu pelayanan kesehatan. Penelitian lebih lanjut tentang faktor-faktor yang paling berpengaruh terhadap kelengkapan dokumentasi keperawatan diperlukan untuk mencari fokus permasalah yang harus segera ditangani.

Pelayanan Kesehatan. Jakarta. Universitas Indonesia.

Huffman, E, K. (1997). Health Information Manajement. Phycian Borwyn Illianois: Record Company.

Kepmenkes No 81/MENKES/SK/I/2004 tentang Pedomanan Penyusunan Perencanaan SDM Kesehatan di tingkat Propinsi, Kab/Kota serta Ruma Sakit.

Mastini, P. (2013). Hubungan Pengetahuan, Sikap dan Beban Kerja dengan Kelengkapan Pendokumentasian Asuhan Keperawatan Irna di Rumah 
Sakit Umum Pusat Sanglah Denpasar. Tesis. Universitas Udayana: tidak di terbitkan

Notoadmodjo, S. (2003). Metodologi Penelitian Kesehatan. Jakarta: PT Rineka Cipta.

Nursalam. (2008). Proses dan Dokumentasi Keperawatan Konsep dan Praktik. Jakarta : Salemba Medika.

Nuryani, N (2014). Hubungan pengetahuan perawat dengan kelengkapan pengisian dokumentasi asuhan keperawatan ruang bedah RSUD dr. Soekardjo Tasikmalaya. Karya Tulis IImiah Perekam dan Informasi Kesehatan. Poltekkes Tasikmalaya: tidak dipublikasikan.
Peraturan Menteri Kesehatan Republik Indonesia Nomor 269/Menkes/Per/III/ 2008 Pasal 1 Tentang Rekam Medis.

Permenkes RI Nomor 269 tahun 2008 Pasal 13 Tentang Pemanfaatan Rekam Medis.

Sugiyono. (2009). Metode Penelitian Keuantitatif Kualitatif dan $R \& D$. Jakarta. CV Alfabeta.

Undang-undang No. 29 tahun 2004 tentang praktik kedokteran.

Undang-undang No. 44 tahun 2009 ayat 1 tentang rumah sakit.

Utami. (2006). Pendokumentasian Asuhan Keperawatan Ditinjau dari Beban Kerja Perawat. Skripsi. FIK UMS: tidak dipublikasikan. 